\title{
OBITUARY
}

\section{SIR RALPH LILLEY TURNER}

Thirty years ago Sir Ralph Turner relinquished tenure of the Chair of Sanskrit in the University of London, of which he had been since 1922 the first full-time holder. Three years later, in 1957, he retired from duty as Director of the University's School of Oriental and African Studies, an appointment which he had held since 1937. During this period of retirement, he completed and (beginning in 1962) published his life's work, the majestic Comparative dictionary of the Indo-Aryan languages. Significant contributions to the historical linguistics of Indo-Aryan continued to appear in the School's Bulletin until 1982 ; and a week before his death on 22 April 1983, in his 95 th year, he was still working on the final revision of a volume of Addenda to the Comparative dictionary.

This achievement, coupled with his personal responsibility as Director of the School of Oriental and African Studies for the development and expansion of Asian and African studies in Britain during the years following 1946, has ensured that the name of Sir Ralph Turner will stand alongside those of Sir William Jones and Sir George Grierson. Like both of them, Sir Ralph had profited from Britain's special relationship with the Indian subcontinent in order to make an inestimable and undying contribution to scholarly research and to the education of both West and East.

The selection of his many articles that was published in 1975 under the title Collected papers 1912-1973 was dedicated to the memory of W. H. D. Rouse, the Headmaster of the Perse Grammar School who had introduced him to Sanskrit, thereby laying the foundations of his career in Indology. As Senior Scholar at Christ's College, Cambridge, he graduated with First Class Honours in both parts of the Classical Tripos (with a special interest in Comparative Philology which contributed towards his achieving Distinction in Part II) and in the Oriental Languages Tripos (with the award of the Brotherton Memorial Sanskrit Prize). His first published research was concerned with the phonology, in particular the accentuation, of Latin and Greek: his paper 'Against the stress accent in Latin' (Classical Review, 1912), which stated the case against the attribution of penultimate stress to Classical and pre-Classical Latin, was a remarkable achievement for a scholar of twenty-three years of age. It is clear that this apprenticeship in the Classics was to equip him as an Indologist with a sense of method and purpose which was denied to others in the field.

Elected a Fellow of Christ's College in 1912, he undertook a linguistic analysis of the Buddhist Sanskrit Dvāvimśatyavadānakathā on the basis of a collation of Cambridge and Paris manuscripts. The excellence of his pioneering exposition (JRAS, 1913) of the corrupt and secondarily hybridized Sanskrit of such relatively late Buddhist works has, unfortunately, rarely been matched by later scholars. The undertaking led to correspondence with Jules Bloch in Paris, and to a close friendship that lasted until the death of Bloch in 1953. This alliance ensured that Turner had the benefit of early access to the proofs of Bloch's Formation de la langue marathe of which general publication was to be delayed for several years by the outbreak of war.

In 1913, he entered the Indian Educational Service and became a teacher of Sanskrit at Queen's College, Benares. An invitation to deliver the Wilson Lectures in Philology at Bombay University (1914) materially assisted him in a special study of the historical phonology of Gujarati. When 'The Indo-äryan nasals in Gujrätī' appeared (JRAS, 1915), there was as yet no satisfactory 
study of any modern Indo-Aryan language in existence. Even recent writers ignored the work of the Neo-grammarians and, as Turner observed, had been 'too often content with saying that such and such a sound develops in two or more ways without attempting to specify the conditions of variation'. The conception of ' optional ' loss of medial nasals, with which Pischel and Grierson (like Hemacandra in the twelfth century) had had to be content, was replaced in the course of this article by a demonstration that the fate of the nasals was subject to rule and depended upon syllabic structure and upon position relative to stress. Such an approach was becoming familiar in the Comparative Philology of Indo-European, but it was new to students of the modern Indian languages. As developed in his major survey ' Gujarāti phonology' (JRAS, 1921 ), and in his post-war teaching, it revolutionized linguistic science in India.

Meantime, in June 1916, Turner, formerly a cadet in the Cambridge University Officer Training Corps and now a Lieutenant in the Indian Army Reserve, joined the $2 / 3$ Gurkha Rifles, a battalion of sappers and miners which had been fighting in France and more recently on Sinai. After a period of responsibility for training Gurkha N.C.O.s in such subjects as bayonet fighting, coupled with efforts to combat plague and other diseases, he went with the battalion up the line to Gaza in June 1917, acting as Company Adjutant or Battalion Staff Officer according to exigency. Nearly one-eighth of the battalion came through the victorious Palestine campaign unscathed, but Turner was wounded in the assault on El Jib near Jerusalem and out of action for five weeks. Eventually, malaria was the only enemy left, and Captain Turner M.C. as Company Commander accompanied the Gurkhas, not to Nepal as they had expected, but to garrison in India en route for a peace-keeping role on the Frontier.

Turner returned with a deep respect and affection for his comrades-in-arms. Witnessing the Gurkhas' gallantry in action, and their impromptu celebration of its comic and tragic incidents as they sat by the Suez Canal or "sheltered in some Cave of Adullam from the rain-storms driving over the bleak stony hills of Judaea or Galilee', he received the inspiration for the Comparative and etymological dictionary of the Nepali language (1931). For more than a generation, this was to confer great distinction upon their language and literature as the standard whereby all other modern Indo-Aryan languages might be evaluated in matters semantic and etymological. The plan that began to take shape in his mind, as he lay wounded in a Cairo military hospital, went beyond this, however, to the all-embracing Comparative dictionary of the Indo-Aryan languages that began to appear 45 years later, in 1962.

By the end of Allenby's Palestine campaign, he had taken down in phonetic transcription, with translation and grammatical notes, the Gurkhas' stories of the advance from Gaza to Jerusalem in November 1917, their exultant song in celebration of the Armistice, and their more epic recollection of earlier campaigns :

tōpai ko phaira d̄ān dānai bhayo Phrãsi kā phātak mãa ; Sikin Tard Gōrkhä bahäduri bhayo Nyūsepal atek mã. tōpai kã gōlā jhimjhimi auundā rāmārām bhanda chan:

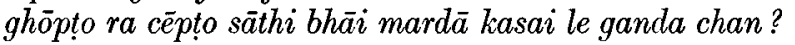
sāthi bhäi bhòkkdā jīu mēro bhījyo ragat kāa thōpà le; Phrãsi mã teso din dinai marthe bairi kã tōpä le. nirbali jüu le haresai khāndā āyōni bukhārai: Phrãsi kā ghar mãa göli ko darai päina uchārai. 
The fire of the guns rumbled in the gateways of France,

gallant deeds were done by the $2 / 3$ Gurkhas in the Battle of Neuve-Chapelle.

The shells of the guns coming like fine rain give greeting,

on their backs and on their faces my friends and brothers dying - shall any count them?

Carrying my friend and brother my body has been wetted with drops of his blood,

in France thus daily they were killed by the guns of the enemy.

When my body was weak and despaired, then came fever,

in the houses of France I found no refuge from the peril of bullets.

These were published as 'Specimens of Nepālī' (Indian Antiquary, 1921, 1922)-alongside 'The infinitive in Nepālì' (Philologica, 1921), a complete statement in less than twelve pages which many a modern linguist, attempting to describe similar phenomena on the basis of exclusively synchronic data, would do well to note.

After demobilization, he had the great good fortune to marry Dorothy Rivers Goulty, who "in the first year of our marriage ... was already engaged in arranging the first collection of slips containing entries for the projected comparative dictionary ' and who continued to support him in all his endeavours for more than fifty years. At the end of 1920, he was deputed to the Benares Hindu University as Professor of Indian Linguistics (so redesignated by his own wish in preference to Comparative Philology). He preached in his Inaugural Address the vision of a national University of India--with a Linguistics Department that would have phonetics laboratories and would undertake analysis of spoken dialects and study manuscript evidence of linguistic history. - There then is a field for research so vast in extent, so fruitful in the contribution it might make to the Science of Language. And as yet it is hardly touched. There is but one complete scientific study of a modern Indian language-the language is Marathi and the book is written in French by a Frenchman. You have allowed a foreigner to take that first honour from you. These are your languages and your heritage : it is for you to join this work, aye and it should be for you to lead the way.' The eleven lectures given at that time as his Introduction to Indo-Aryan were not published, but they survive in manuscript.

He occupied the Chair for only two of the five years intended, but even during that space of time he helped to inspire a whole generation of Indian scholars to accept the challenge. Baburam Saksena was his first student, followed by Siddheshwar Varma and S. M. Katre, together with B. D. Jain, B. S. Pandit, and Raghu Vira. Each one of them went on to make a significant contribution to knowledge. Turner's election in 1922 to the Chair of Sanskrit in London University, tenable at the recently established School of Oriental Studies, did not break this link, but rather helped to encourage an advantageous exchange of staff and students: S. K. Chatterji's philological analysis of Bengali owed much to a sojourn in London, and the work of P. B. F. Wijeratne and T. N. Dave has considerably enriched the corpus of Sinhalese and Gujarati lexical material respectively. 
Without the transfer to London, Turner's contribution to research would have been less: '. . in the case of comparative philology, unless I happen to possess a particular book myself, there is little hope that I shall find access to it in India' (JRAS, 1916). As a result of vacations spent in Almora, Nainital, etc., he had extended his interest to Kumaoni and West Pahari. In London, he came into personal contact with Grierson, Grahame Bailey, Lorimer, and Morgenstierne, and he acquired a complete stock of published works on Romani.

Thus he was able gradually to extend his scope further towards the Indian dialects of the Himalaya and Hindu Kush and towards Asiatic and European Gypsy. His publications between 1922 and the date of the Nepali dictionary were devoted to clearing up outstanding difficulties in the languages of the North West, beginning with the much debated development of Sindhi recursives (BSOS, 1924) and Sindhi cerebrals (JRAS, 1924, 1925). Again, Turner's ability to explain the phenomena in terms of historical phonology led to drastic simplifications of the issues involved. Similarly, in The position of Romani in Indo-Aryan (1927) he showed that both those who favoured the theory of a North-Western origin for the Gypsy dialects and those who opposed it were guilty of serious misconceptions. They had tended to equate significant common innovations with instances of accidental common conservation; they had sought to compare modern forms of Gypsy with modern forms of Hindi, etc., without reference to historical evolution. As Grahame Bailey observed, these objections appear self-evident when stated, and yet they were very generally ignored. Turner's demonstration that Romani is simply a very early off-shoot from the generality of Indo-Aryan languages of Northern India seems to have settled the matter, at least until such time as a much clearer chronology of linguistic change in India can be achieved. Further contributions to the philology of Romani followed at intervals until 1960.

After the publication of the Nepali dictionary in 1931, and while the plan was being developed for an Indo-Aryan dictionary arranged under Sanskrit headwords, his minor publications tended to concentrate thenceforth on the solution of individual problems in Middle Indo-Aryan. He was invited to make a comparative study (for the Hyderabad Archaeological Series, 1932) of two newly discovered copies of a Minor Rock Edict of Aśoka at Gavimath and Pālkīguṇu (not far from Hampi in Karnataka), and this clearly fostered an interest in the dialect structure of Prakrit. The article 'Sanskrit $\bar{a}-k s+t i$ and Pali acchati in Modern Indo-Aryan' (BSOS, 1936) is notable for its inclusion of a sketch-map of isoglosses : few scholars apart from Grierson and Turner have been prepared to apply the techniques of linguistic geography in the field of Indian language.

By this time, however, administrative responsibility had begun to obtrude, and in 1937, after he had held the Chair of Sanskrit there for fifteen years, Turner accepted the challenge of appointment as Director of the School of Oriental Studies.

It was a time of some optimism for the future of Oriental studies in London, and for the School itself. The twenty years since its foundation during the First World War had been a period of constant struggle for survival. It had been provided with a home in the building of the former London Institution in Finsbury Circus, but its income was always inadequate and insecure, and despite the encouragement and support of the University of London there had been little possibility of a planned development of the School's studies. Then, in the mid-thirties, things seemed about to change for the better. As part of the development of its new Bloomsbury precinct the University offered the 
School a site there. The sale of the Finsbury Circus building was expected to produce a sum sufficient not only to cover the costs of a new building in Bloomsbury, but to provide also a capital sum the income from which might support the academic developments that closer links with the University might be expected to stimulate. The University's offer was therefore accepted and the Finsbury building sold in 1936 for $£ 219,000$. Since the School's new home in Bloomsbury was expected to cost at most $£ 150,000$ it must have been with high hopes that the new Director assumed office in temporarily rented accommodation in Westminster, and began to make plans for the academic development which would mark the move to Bloomsbury early in 1941.

In fact the first decade of Turner's Directorship was, for the most part, a period of turmoil and crisis in which his courage, acumen, and energy were taxed to the full. He was concerned from the beginning to widen the basis of the School's studies. Already a grant from the Rockefeller Foundation had made possible the launching of a series of research projects in African linguistics, and led to the setting up of a Department of African Languages and Cultures, and in 1938 'Africa ' was added to the School's title. An approach through the Colonial Office brought additional grants from colonial governments in Africa and Asia to sustain and extend work in the relevant language fields. Emboldened by this success, Turner then arranged for a deputation from the Court of the University to call on the Secretaries of State for India and the Colonies and the Financial Secretary of the War Office and impress on them the importance of maintaining in London a centre of Asian and African studies which in the national interest was at least as comprehensive and effective as the centres of these studies in the other major European states. In the threatening international situation of 1938 these representations were listened to. Turner's advocacy resulted in the three Departments of State, together with the Foreign Office, setting up an Inter-Departmental Committee to consider the School's 'Case for Increased Financial Assistance', a document of 49 printed pages. The Committee was convinced, and agreed that the School's normal income of $£ 30,000$ ought to be brought up to about $£ 55,000$ by an additional Treasury grant. The Treasury thought not. They had been generous enough, wrote Sir John Simon, in allowing the School to keep the entire proceeds from the sale of Finsbury Circus; the expansion now proposed would have to wait for 'happier times'. That was in February 1939. Before March was out the indomitable Turner had, none the less, persuaded the University itself to find the cost of five additional posts in Japanese, Turkish, and Arabic, on the grounds that they would be needed to meet the demands of the Services for language training in the event of war.

When war broke out in September 1939 Turner took the School to Cambridge, where arrangements had been made for it to receive hospitality and shelter from the expected heavy bombing of the capital at Christ's, his own college. But the bombing did not at once materialize, the School's students dwindled away, and although the Department of Phonetics and Linguistics was able to give important help to the solution of the RAF's problems with radio telephony, Turner felt that for him and his colleagues to make a full contribution to the national interest they must be in day-to-day contact with the Government Departments and with their own Library, which had remained in London. Despite much contrary advice his views eventually prevailed.

In July 1940 Ralph Turner and those of his colleagues who had not been directed into other forms of war service returned once more to temporary accommodation in Westminster. He at once became involved in two arduous 
campaigns, one to secure for the School possession of its Bloomsbury building, now approaching completion, the other to convince the Service Ministries of the importance of a supply of personnel trained in key Asian languages, and the simple truth that the time to set up the necessary training programmes was before (rather than after) the lack of such personnel had begun to hamper operations.

Early in 1941, when two-thirds of the Bloomsbury building was expected to be completed in June, Turner became aware of the Government's intention to requisition it for the use of the Ministry of Information. A compromise plan which he put forward to divide the accommodation between the School and the Ministry was at first rejected, but Turner persisted, and thanks to energetic support from Sir Philip Hartog and Lord Hailey (then Chairman of the School's Governing Body) the School was at last able to move into a portion of the partly-completed building in October. But this was only the first round. The dispute came to a head again in the summer of 1942 , when a move was started to evict the School from the building so that the whole of the premises might be taken over by the Ministry of Information. Turner responded with a memorandum to the Service Ministries saying that their increasing demands for language courses resulting from the outbreak of war with Japan could not be met unless the Ministry of Information was moved out altogether, and asking them to use their influence to have the Ministry ejected. Battle was then joined, the School being supported by the Service Ministries, the Ministry of Information by the Ministry of Works. At a critical point in the exchanges Hailey was compelled to undertake a mission to the United States, but Turner, ably supported by Hartog, marshalled his forces with great coolness and skill, and after veritable barrages of memoranda had been exchanged and the battle had been taken to the House of Commons and the Cabinet itself, a solution was found in February 1943. The still unfinished shell of the East wing of the Bloomsbury building was to be completed by the Government at its own expense and occupied by the Ministry of Information, the School being granted unchallenged occupation of the major part of the remainder.

Whilst the battle of the building was being waged, Turner was also engaged in the uphill task of providing language training for Service personnel. The recruitment of competent instructors and the organization of courses asked for by the Services in the first three years of the war (mainly in Arabic, Turkish, and Urdu) would in the prevailing circumstances have been difficult enough. Even more discouraging was the task of convincing the Services of their future needs in time for the resources necessary to meet them to be provided. An approach to the War Office on the urgent necessity to remedy the acute shortage of men able to speak and read Japanese was met in August 1941 by the assurance that ' we are at present reasonably insured in the matter of officers knowing Oriental languages'. In 1942, when he raised the question of training in Chinese he was told that educated Chinese spoke English; our liaison officers had no need to speak Chinese. Gradually, however, in response to his efforts and the inexorable logic of events, the tide turned. The demand from the Services for intensive courses steadily grew until at its peak in the session 1943-44 nearly 1,000 servicemen entered the School.

By then, however, Ralph Turner's thoughts had already turned to the future, and to the 'happier times' to which in 1939 the Chancellor of the Exchequer had postponed the planned development of the School and its studies. As a result of Turner's initiative the Principal of the University was induced to write to the School in November 1943 asking for a report on its 
post-war plans, and a set of proposals calling for the expansion of the academic staff to more than 150, compared with the 42 teachers in post at the outbreak of the war, was forwarded to the University early in March 1944. This was ambitious enough, but more was to follow. For some time Turner had been in correspondence with the India Office and the Foreign Office about likely political developments in Asia and Africa after the war, and the need for expertise in Oriental and African studies in Britain in the post-war world. In February 1944 he and Lord Hailey were able to talk to Anthony Eden, then Foreign Secretary, and in June Eden wrote to Hailey announcing his decision to set up a Commission of Enquiry into means of improving the study in Britain of Oriental, African, Slavonic and East European languages and cultures.

The Commission's Report, completed in 1946, was a turning-point in the development of Oriental and African studies. Turner's experience of official apathy or lack of foresight made him determined to do all in his power to ensure that (as he put it to Lord Scarbrough, the Chairman of the Commission in 1945) the improvisations of peace should not be even less effective than the improvisations of war. He worked tirelessly in plying the Commission with facts and in seeing to it that anyone with relevant evidence to give should have the opportunity to do so. To Turner more than any other man must go the credit for the Commission's appointment, and a large share of the credit for the speed with which it worked and with which its recommendations were accepted. The financial provision which was thus assured for the expansion and development of Oriental and African studies, not only in London but in other British universities, and for the creation of studentships for the training of younger scholars, secured the future of these studies for a generation.

For Ralph Turner the years which followed were no less demanding than the period of pre-war penury and wartime improvisation had been. The building of strong departments in all the School's fields of study, and the recruitment and training of young scholars to work in them taxed the energy and resourcefulness of himself and his senior colleagues to the full. But the conditions in which he worked were quite different. The School was now reunited with its Library in sole possession of the Bloomsbury building, though this accommodation itself soon became cramped as the academic staff expanded from 90 in 1947 to 145 in 1957. Progressively much of the burden of day-to-day administration and practical organization which he had carried during the war was lifted from his shoulders by a more adequate and settled body of professional administrative staff. Above all there was a new sense of security which stemmed from the knowledge that the importance of his work and the goals for which he strove had now been acknowledged by authorities outside the School and the University.

Turner's own contribution towards this achievement was recognized in 1950 by the bestowal of knighthood. He had already become a member of the Colonial Social Science Research Council, the Treasury Committee for Studentships in Foreign Languages and Cultures and the UGC's Oriental and African Studies Committee. His contributions to these bodies were of the very greatest importance for the future development of these fields, as was the time he found to devote to the affairs of the Philological Society and the Royal Asiatic Society, both of which he served as President.

When he retired from the Directorship of the School in 1957 his successor pard eloquent tribute to the inspiration and devotion with which he had served it. His success in guiding it through many perils and setting it on a new and more prosperous course was attributable not only to his gifts of intellect 
and imagination, but also to the trust and affection which his integrity inspired in his colleagues.

Now, in his seventieth year, he could devote himself to the task of completing his academic life's work, the Indo-Aryan dictionary. For twenty years the huge collection of hand-written slips had suffered neglect-and even precautionary interment (to be precise, in a kitchen midden at his home in Bishop's Stortford) for the duration of the Second World War, as the attention of the School and its Director was of necessity directed elsewhere. Posterity could be entrusted with the task of supplementing the available material ; but the basic plan of relying upon existing published etymologies called for a great deal of essential editorial intervention at this stage, and this had to be achieved without delaying one of the most difficult typographical exercises ever to have been imposed upon a printer. Turner's customary self-discipline won the day. The Comparative dictionary of the Indo-Aryan languages, comprising some 140,000 words arranged under the 15,000 Sanskrit or Sanskrit-related etyma from which they appear to derive, was published by Oxford University Press in 1966 (in fascicles from 1962). There followed Indexes to the various languages compiled by Dorothy Rivers Turner (1966), and a Phonetic analysis of the entire corpus of material, again based on the work of his wife, but introducing to Indian lexicography the use of computer analysis (1971). 'One of the most outstanding events in the history of Indian linguistic studies' (Katre), it took its place as a basis for all subsequent research beside Grierson's monumental Linguistic survey of India (1903-27), of which it was long intended to form the concluding volume.

The range of published sources drawn upon is much more complete than was possible at the time of the Nepali dictionary and the number of languages and dialects covered is considerably larger. One interesting feature, to which Sir Ralph himself drew attention, is the "Preservation of original Aryan vocabulary in the modern languages' (BSOAS, 1979), as when the more peripheral dialects occasionally retain Vedic vocabulary which has been lost elsewhere, or as when the generality of modern languages seem to attest ancient words which, however, are poorly attested in early sources. Already supplementary lists have been published by other scholars. The fourth Addenda volume, on which he was still working at the time of his death, will shortly be published by the School of Oriental and African Studies.

Between 1957 and 1982, eleven scholarly articles were published, dealing with the lexical and phonological problems that had continued to arise in connexion with the Dictionary, e.g. puzzles like the relation between Ashkun būra 'mind' and Skt. buddhi- (Indo-Iranica, 1964) or Pali ädāsa-and Skt. $\bar{a}$ darśa- $(B S O A S, 1967,1973)$. All but three late pieces are included in his Collected papers 1912-1973 (OUP, 1975) together with some appended comments by the author. His last article, in 1982, remained as much a model of concise and careful scholarship as his first, published in 1912. His task ended with the re-copying of a slip containing addenda to Dictionary entry no. 6672 dvāvimśati 'twenty two': it registered new attestations from Himalayan Kotgarh and from the Maldives to be added to the list of descendants, culled from other modern languages of India, Nepal, Sri Lanka, Pakistan, and Bangladesh, that had been given in the Dictionary proper.

The word ' kindliness' is probably not one that is often applied to a captain of the Gurkha Rifles, to the director of a university college, or to a professor of Sanskrit, but there is no doubt but that it best defines one's abiding impression of Sir Ralph. We may perhaps be forgiven for glancing into the garland 
of verses Bhärata-māla, in which he sought to perpetuate for himself and his wife a personal and yet widely shared experience of India:

.. They are exiles from their homeland,
From their green and pleasant homeland :
Yet for them is great ambition
In upholding high tradition
Of a distant race and country,
Making fair the name of England,
Treading in the path of duty.
And for ever following after,
Wheresoe'er that path may lead them,
They will hear the voice of India,
Calling to them, calling always.

Though he was knighted in 1950, awarded the Litt.D. degree of Cambridge University and the honorary D.Lit. degrees of the Universities of Benares, Ceylon, London, Santiniketan, and Kathmandu, and invested with innumerable honorary appointments, he would cherish still more such a presentation as that which came to him from $\mathrm{O}$. H. de A. Wijesekera in the form of a scholarly work entitled $A \tilde{n}$ jali and inscribed personally 'To my beloved Guru'. He took especial pride also in his election to an Honorary Fellowship of Christ's College, Cambridge-Alma Mater now of three successive generations of Turners-and in his investiture by two successive Kings of Nepal with the Order of Gorkhā Dakșina Bāhu and the Order of Gorkhā Dakșina Bāhu First Class. It seems impossible to remember Sir Ralph without remembering too his personal testament, the closing words of his Inaugural Address to the Benares Hindu University :

... from that common sharing of toil and hardship and danger, wounds and death, from the common striving towards a common goal, was born a comradeship, which while I live can never be effaced from my memory. The cause of that association, those of us who fought, pray may in the future be but a past episode in the world's history, out of which mankind has for ever grown. For war must go. But that thing which many found in war shall continue-the comradeship born of a common striving for a common goal. No goal is more worthy of that common striving than the the goal of knowledge. And those that seek that goal together shall know the comradeship, highest reward of all human effort. The path to knowledge is laborious; the road is long and difficult. It calls for high endeavour and the nobility of sacrifice. But this reward awaits the traveller: 'He was of those who strove to advance knowledge among men'.

\section{J. C. Wright and C. D. Cowan}

